\title{
Development of sensitive, high-throughput one-tube RT-PCR-enzyme hybridisation assay to detect selected bacterial fish pathogens
}

\author{
T. Wilson ${ }^{1,2, *}$, J. Carson ${ }^{1}$ \\ ${ }^{1}$ Fish Health Unit, Tasmanian Aquaculture and Fisheries Institute, University of Tasmania, Launceston, Tasmania 7249, Australia \\ ${ }^{2}$ Fish Health Unit, Department of Primary Industries, Water and Environment, PO Box 46, Kings Meadows, Launceston, \\ Tasmania 7249, Australia
}

\begin{abstract}
Bacterial monitoring and surveillance is critical for the early detection of pathogens to avoid the spread of disease. To facilitate this, an efficient, high-performance and high-throughput method to detect the presence of femotgram amounts of ribosomal RNA from 4 bacterial fish pathogens: Aeromonas salmonicida; Tenacibaculum maritimum (formerly Flexibacter maritimus); Lactococcus garvieae; and Yersinia ruckeri was developed. The system uses NucleoLink ${ }^{\mathrm{TM}}$ strips for liquid- and solid-phase PCR in 1 tube, to perform RT-PCR-enzyme hybridisation assays (RT-PCREHA) detecting $4 \mathrm{fg}$ or less of rRNA from pure cultures and between 1 and 9 CFU per $200 \mu$ sample volume from selective-enrichment culture media. The liquid-phase amplicons were visualised by gel electrophoresis and the solid-phase amplicons detected using internal probes and visualised using colorimetric detection and $p$-nitrophenylphosphate.
\end{abstract}

KEY WORDS: RT-PCR-EHA · RT-PCR-ELISA · NucleoLink · High-throughput · Hybridisation

Resale or republication not permitted without written consent of the publisher

\section{INTRODUCTION}

Asymptomatic carriage of bacterial pathogens poses a serious risk for the spread of disease in fish populations. With covert infection, fishes show no signs of disease although the bacterium is present within the host. It is only when the fishes are stressed that the disease becomes evident. Under aquaculture conditions the risk of stress is increased and a significant proportion of the stock may become infected. Consequently, the detection of asymptomatic carriers is an essential strategy for effective disease control (Bullock \& Stuckey 1975).

Statistically relevant disease surveillance and monitoring requires testing large numbers of fish. A system that accommodates high numbers of samples needs to be streamlined, high-throughput and involve minimal handling of samples at every step. Therefore, to detect asymptomatic carriage of bacterial pathogens in fish, a cost-effective, high-throughput, sensitive and specific system is required for surveillance and monitoring purposes.

Reverse transcriptase polymerase chain reaction (RT-PCR) is a well-developed technique used to detect specific RNA sequences and determine levels of gene expression (Koo \& Jaykus 2000). The sensitivity and specificity achieved in a well-designed RT-PCR make it an ideal tool for use in the surveillance and monitoring of covert infections. The high sensitivity of RT-PCR makes the detection of very low numbers of bacteria possible and, due to the short half-life of RNA compared with DNA, RT-PCR gives a more accurate approximation of live bacterial carriage than regular PCR. However, restrictions due to sample size, the presence of non-target nucleic acids, PCR inhibitors and the logistics of high-throughput sampling could limit its usefulness.

The restrictions posed by sample size and non-target nucleic acids can be addressed by coupling PCR with selective-enrichment culture (Thisted Lambertz et al. 
1996). Selective-enrichment increases the amount of target bacterium and helps reduce the number of competing microflora (Fitter et al. 1992, Swaminathan \& Feng 1994, Witham et al. 1996). The impact of PCR inhibitors such as selective components and fish tissues can be minimised by using a high-throughput and high-quality nucleic acid extraction system (Wilson \& Carson 2001). When performing RT-PCR, handling RNA pre-PCR can be minimised by using a 1-step RTPCR protocol. This saves time, reduces costs and decreases the chance of false-positive reactions arising from excessive handling and pipetting (Limbach et al. 1999). Large numbers of samples are most easily processed in a 96-well system. While most thermal cyclers accommodate a 96-well format, visualisation of highthroughput RT-PCR amplicons by gel electrophoresis is cumbersome and laborious. Also, the diagnostic result produced from gel electrophoresis relies wholly on the specificity of the primers and the stringency of the PCR reaction conditions. For disease diagnosis, an increased level of confidence is desired and can be achieved with a specific internal probe that verifies the amplicon sequence.

The most convenient high-throughput DNA hybridisation technique uses 96-well micro-well ELISA-like technology. These methods can be significantly more sensitive than Southern blotting, and processing time is greatly decreased through shorter hybridisation times and easier high-throughput sample-processing. Current RT-PCR-ELISA methods typically suffer from excessive handling, as RT-PCR amplicons are manually transferred from the PCR to the ELISA tray (Barlic-Maganja \& Grom 2001, Liolios et al. 2001, Rey et al. 2001), thereby increasing cost, time and, importantly, the risk of cross-contamination. A protocol for the amplification and verification of PCR amplicon in a 1tube system would be highly desirable, particularly for diagnostic applications.

PCR-enzyme hybridisation has been developed in a 1-tube format for the amplification and detection of DNA (NucleoLink ${ }^{\mathrm{TM}}$, Nalge Nunc International) and optimised to suit specific bacterial pathogens (Grennan et al. 2001, Wilson et al. 2002). Using this system, a biphase PCR reaction occurs, with amplicon generated bound to the surface and free in liquid phase. The proprietary term for this process is 'Detection of Immobilised Amplified Product in a One-Phase System (DIAPOPS)' (Nalge Nunc International). To date there are no publications describing the use of NucleoLink to perform 1-tube RT-PCR-enzyme hybridisation assays (RT-PCR-EHA).

This study describes the development of RT-PCREHA in NucleoLink tubes to produce a sensitive, low cost, 1-tube protocol for detecting the presence of femtogram amounts of rRNA from 4 bacterial fish pathogens Aeromonas salmonicida, Tenacibaculum maritimum (formerly Flexibacter maritimus), Lactococcus garvieae and Yersinia ruckeri. The system is optimised using purified rRNA and then used to detect rRNA from bacteria grown in selective-enrichment media.

\section{MATERIALS AND METHODS}

Cultures. Unless otherwise specified, all bacteria were obtained from the culture collection held by the Fish Health Unit, Department of Primary Industries, Water and Environment, Tasmania.

Target organisms. Atypical Aeromonas salmonicida isolated from greenback flounder (Whittington et al. 1995), DPIWE Accession No. 93/956-2; Tenacibaculum maritimum NCIMB $2154^{\mathrm{T}}$; Lactococcus garvieae ATCC $49156^{\mathrm{T}}$; and Yersinia ruckeri Serotype O1b isolated from Atlantic salmon, DPIWE Accession No. 90/3988 were used in this study.

Specificity organisms. The specificity of the RTPCR-EHA system was assessed at 2 levels: firstly, using phenotypically similar bacteria, near related species and bacteria likely to be isolated alongside the target bacterium; secondly, using bacteria identified as having some genotypic similarity in respect to the specific 16S rRNA primer sequence as identified by Carson (1998). The bacteria tested for each of the 4 bacteria are listed in Table 1.

16S rRNA primers and internal probes. 16S rRNA primer sets (Carson 1998) were used for the PCR assays. The properties of the resulting amplicons were as follows: Aeromonas salmonicida (261 bp, $55 \%$ $\mathrm{G}+\mathrm{C})$; Tenacibaculum maritimum (288 bp, $49 \% \mathrm{G}+\mathrm{C})$; Lactococcus garvieae (145 bp, 46\% G + C) and Yersinia ruckeri (247 bp, $54 \% \mathrm{G}+\mathrm{C}$ ). For each RT-PCREHA the reverse primer was chosen as the solid-phase primer. Solid-phase primers were modified by the addition of a 10-base thymidine linker to the 5 '-end of the primer and phosphorylation at the end of this linker, as recommended by Nalge Nunc International.

The internal biotin-labelled probes used for hybridisation to the solid-phase RT-PCR products were developed by Carson (1998), except the Aeromonas salmonicida probe, which was described by Høie et al. (1997).

RNA extraction. Pure and target RNA were extracted as folows:

Pure rRNA: Pure target RNA was obtained using an RNAAqueous $^{\mathrm{TM}}$-4PCR (Ambion) extraction kit following the manufacturer's instructions. RNA concentration was measured at an $\mathrm{A}_{260}: \mathrm{A}_{280}$ absorbance ratio using a Genequant DNA/RNA calculator (Pharmacia Biotech). 
Target RNA from selective-enrichment media: Bacterial RNA from the selective-enrichment samples was extracted using the rapid, high-throughput DNA extraction method described by Wilson \& Carson (2001) with some modifications for the extraction of RNA. Briefly: all extraction reagents were prepared with solvents treated with $0.2 \%(\mathrm{v} / \mathrm{v})$ diethyl pyrocarbonate (DEPC). Lysis, DNA binding and elution were performed using a Polyfiltronics glass microfibre (Type GF/B) $800 \mu l$, 96-well Uni-filter plate, and a UniVac vacuum manifold (Whatman). The filter wells were treated with water containing $0.2 \%(\mathrm{v} / \mathrm{v})$ DEPC for at least $2 \mathrm{~h}$ prior to extraction. After treatment the wells were drained by applying a vacuum of about $20 \mathrm{kPa}$ for about $1 \mathrm{~min}$. A volume of $500 \mu \mathrm{l}$ cold guanidinium isothiocyanate buffer (L6) with $1 \%$ (v/v) $\beta$-mercaptoethanol was added to each well, and $200 \mu$ of the sample (selective-enrichment medium seeded with bacteria) was then added to the appropriate filter well. After $15 \mathrm{~min}$, the lysate was removed from the filter wells by applying a vacuum of about $13.5 \mathrm{kPa}$. The wells were washed twice with $100 \mu \mathrm{l}$ of buffer (L2) and

Table 1. Bacteria used for testing specificity of RT-PCR-EHA. Homology: \% in respect to primer of closest match; FCLB: unidentified Flexibacter-Cytophaga-like normal flora isolated from Atlantic salmon

\begin{tabular}{|c|c|c|c|c|c|}
\hline Species & Strain no. & Homology & Species & Strain no. & Homology \\
\hline \multicolumn{3}{|c|}{ Aeromonas salmonicida-specificity } & \multicolumn{3}{|c|}{ Lactococcus garvieae-specificity } \\
\hline A. salmonicida ${ }^{\mathrm{a}}$ & 84/09062-B13 & $100 \%$ & Carnobacterium piscicola & ATCC $35586^{\mathrm{T}}$ & $76 \%$ \\
\hline A. sobria & ATCC $43979^{\mathrm{T}}$ & $100 \%$ & Flavobacterium columnare & NCIMB $2248^{\mathrm{T}}$ & $71 \%$ \\
\hline A. eucrenophila & ATCC $23309^{\mathrm{T}}$ & $94 \%$ & Streptococcus sp. ${ }^{\mathrm{d}}$ & CORT 1 & \\
\hline A. jandaei & ATCC $49568^{\mathrm{T}}$ & $94 \%$ & Streptococcus sp. ${ }^{\mathrm{d}}$ & CORT 2 & \\
\hline A. schubertii & ATCC $43700^{\mathrm{T}}$ & $94 \%$ & L. piscium & NCDO $2778^{\mathrm{T}}$ & \\
\hline A. veronii bv sobria & ATCC $9071^{\mathrm{T}}$ & $94 \%$ & S. iniae ${ }^{\mathrm{c}}$ & QDPI 95/41693-4a & \\
\hline A. veronii bv veronii & ATCC $35624^{\mathrm{T}}$ & $94 \%$ & Enterococcus faecalis & ATCC 29212 & \\
\hline A. hydrophila & ATCC $7966^{\mathrm{T}}$ & $85 \%$ & Vagococcus salmoninarum & NCDO $2777^{\mathrm{T}}$ & \\
\hline A. hydrophila & ATCC 7965 & $85 \%$ & A. hydrophila & $\operatorname{ATCC~} 7966^{\mathrm{T}}$ & \\
\hline A. hydrophila ${ }^{\mathrm{b}}$ & UTS 67 & $85 \%$ & \multirow{2}{*}{\multicolumn{3}{|c|}{ Yersinia ruckeri-specificity }} \\
\hline A. bestiarum & ATCC 14715 & $85 \%$ & & & \\
\hline A. caviae & ATCC $15468^{\mathrm{T}}$ & $76 \%$ & Y. pseudotuberculosis & $96 / 5417-2$ & $96 \%$ \\
\hline A. trota & ATCC $49657^{\mathrm{T}}$ & $76 \%$ & $Y$. enterocolitica & $96 / 5440-1 \mathrm{~B}$ & $87.5 \%$ \\
\hline A. media & ATCC $33907^{\mathrm{T}}$ & $75 \%$ & Haemophilus influenzae & ATCC $33391^{\mathrm{T}}$ & $68 \%$ \\
\hline Vagococcus salmoninarum & NCDO $2777^{\mathrm{T}}$ & & Citrobacter freundii & $90 / 2624-18$ & $87.5 \%$ \\
\hline Tenacibaculum maritimum & NCIMB $2154^{\mathrm{T}}$ & & $Y$. intermedia & $92 / 4041$ & \\
\hline Hafnia alvei & $95 / 6404$ & & H. alvei & $95 / 6404$ & $87.5 \%$ \\
\hline Proteus rettcreri & $96 / 5494$ & & Proteus rettqeri & $96 / 5494$ & \\
\hline Yersinia intermedia & $92 / 4041$ & & V. angullarum & $85 / 3475-1$ & \\
\hline Aeromonas sp. ${ }^{\mathrm{d}}$ & NF 1 & & Carnobacterium piscicola & ATCC $35586^{\mathrm{T}}$ & \\
\hline Aeromonas sp. ${ }^{\mathrm{d}}$ & NF 2 & & V. salmoninarum & NCDO $2777^{\mathrm{T}}$ & \\
\hline Pseudomonas sp. ${ }^{\mathrm{d}}$ & NF 3 & & Pseudomonas sp. ${ }^{\mathrm{d}}$ & NF 3 & \\
\hline Enterobacter sp. ${ }^{\mathrm{d}}$ & NF 4 & & Enterobacter sp. ${ }^{\mathrm{d}}$ & NF 4 & \\
\hline \multicolumn{3}{|c|}{ Tenacibaculum maritimum-specificity } & \\
\hline Cytophage marinoflava & ACAM 75 & \multirow[t]{11}{*}{$65 \%$} & \multicolumn{3}{|c|}{ Specificity: all systems } \\
\hline T. ovolyticum & NCIMB $13127^{\mathrm{T}}$ & & \multicolumn{3}{|c|}{ Atypical Aeromonas salmonicida 93/0956-2 } \\
\hline FCLB mucoid & $89 / 2244-9$ & & Escherichia coli & ATCC 25922 & $\begin{array}{c}87.5 \% \\
\text { Y ruckeri) }\end{array}$ \\
\hline FCLB mucoid & $89 / 2756-1$ & & L. garvieae & ATCC $49156^{\mathrm{T}}$ & \\
\hline FCLB mucoid & $96 / 5171$ & & Y. ruckeri serotype $\mathrm{O} 1 \mathrm{~b}$ & $90 / 3988$ & \\
\hline FCLB mucoid & CRC-2 & & & & \\
\hline Flavobacterium columnare & NCIMB $2248^{\mathrm{T}}$ & & & & \\
\hline F. johnsoniae & ATCC $17061^{\text {Co-T }}$ & & & & \\
\hline Vibrio splendidus bv I & ATCC $25914^{\mathrm{T}}$ & & & & \\
\hline V. ordalii & ATCC $33509^{\mathrm{T}}$ & & & & \\
\hline V. anguillarum & $85 / 3475-1$ & & & & \\
\hline \multicolumn{6}{|c|}{ 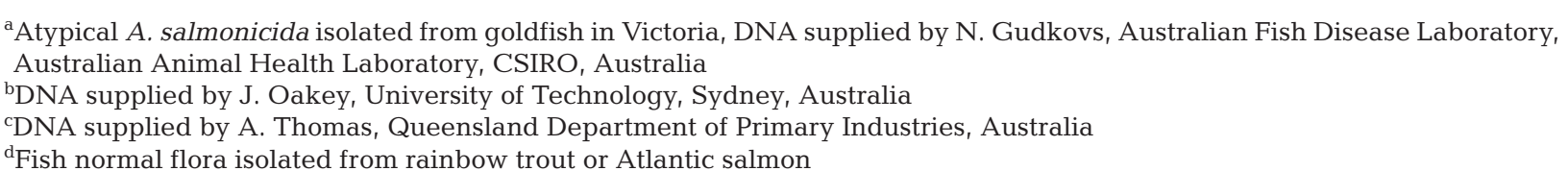 } \\
\hline
\end{tabular}


then washed 5 times with $200 \mu$ of $70 \%$ ethanol and once with acetone, at a vacuum pressure of $40 \mathrm{kPa}$. The vacuum was allowed to run until there was no visible trace of solvents in the wells or on the drip directors underneath the wells (usually $5 \mathrm{~min}$ ); $30 \mu \mathrm{l}$ of sterile DEPC-treated water, pre-heated to $90^{\circ} \mathrm{C}$, was then added to each filter well. After $10 \mathrm{~min}$, the nucleic acids were eluted from the glass microfibre-filter plate. A further $20 \mu \mathrm{l}$ of pre-heated water was added to the wells and allowed to stand for $2 \mathrm{~min}$, after which time the final elute was collected by vacuum and rehydrated overnight at $4^{\circ} \mathrm{C}$.

Specificity bacteria. Organisms used for specificity testing were grown in pure culture and then suspended in $100 \mu \mathrm{l}$ of DEPC-treated 18 Mohm water. Nucleic acids were extracted by boiling for $15 \mathrm{~min}$ and cooling rapidly to $-20^{\circ} \mathrm{C}$ for $5 \mathrm{~min}$ followed by a $10 \mathrm{~min}$ centrifuge at $18000 \times g$. The nucleic acids (supernatant) were then transferred to a clean sterile tube.

DNase treatment of RNA. Immediately prior to RT-PCR, $1.4 \mu \mathrm{l}$ of DNase buffer $(1 \mathrm{mM} \mathrm{MnCl} 2,1 \mathrm{mM}$ $\mathrm{CaCl}_{2}$ and $0.1 \mathrm{M}$ Tris-HCl pH 8.0) with $0.5 \mathrm{U}$ DNase (Promega) was added to $5 \mu \mathrm{l}$ of nucleic acid extract. The samples were incubated for $30 \mathrm{~min}$ at $37^{\circ} \mathrm{C}$ followed by denaturation at $75^{\circ} \mathrm{C}$ for $5 \mathrm{~min}$, and cooled to $4^{\circ} \mathrm{C}$ for at least $1 \mathrm{~min}$.

Determination of sensitivity. Test sensitivity was determined at 2 levels, firstly with pure target RNA and secondly with RNA extracted from selectiveenrichment media: HK for Aeromonas salmonicida; POSI for Tenacibaculum maritimum; CORT for Lactococcus garvieae; and POST for Yersinia ruckeri (T. Wilson \& J. Carson, proprietary formulations, Cooperative Research Centre for Aquaculture, Sydney) using the vacuum system described here. For the pure RNA, serial dilutions were prepared from RNA of known concentration and these dilutions were amplified by RT-PCR. For the RNA from selectiveenrichment media, a $0.5 \mathrm{McF}$ arland suspension of bacteria in log-phase of growth was prepared in sterile water. From this a 1:1000 dilution followed by 10 decimal dilutions using the selective-enrichment media as diluent were prepared. Just prior to RNA extraction, viable counts of the suspensions were determined by the Miles \& Misra method (Miles et al. 1938) using Shiehs medium (Song et al. 1988) for the T. maritimum and blood agar base No. 2 (Oxoid) supplemented with $7 \%$ (v/v) defibrinated sheep blood (SBA) for the other bacteria; plates were incubated for $48 \mathrm{~h}$ at $25^{\circ} \mathrm{C}$. Bacterial RNA from each of the decimal dilutions was immediately extracted as described above, and the RNA amplified by RT-PCR-EHA.

Binding of solid-phase primer to microwells. The modified reverse primers were covalently bound to the NucleoLink strips by the carbodiimide condensation reaction (CCR) as described for the Covalink $\mathrm{NH}$ BreakApart $^{\mathrm{TM}}$ strips (Rasmussen et al. 1994). CCR reagent, sufficient for one 8-well strip, was prepared by adding $1.63 \mathrm{mg}$ of 1ethyl-3-(3-dimethylaminopropyl)-carbodiimide (EDC) to $840 \mu \mathrm{l}$ of $18 \mathrm{Mohm}$ water, $8.5 \mu \mathrm{l}$ of $1 \mathrm{M}$ 1-methylimidazole (1-MeIm) and $0.85 \mu \mathrm{l}$ of $1000 \mathrm{ng} \mathrm{ul}^{-1}$ of solid-phase primer. NucleoLink strips were placed into a Nunc Frame (Catalogue no. 249182), and a $100 \mu \mathrm{l}$ aliquot of CCR reagent solution was added to each well. The strips were sealed with Nunc Tape 8 (Catalogue no. 249719) and incubated at $50^{\circ} \mathrm{C}$ for $5 \mathrm{~h}$. After incubation, non-covalently bound primer was removed by washing 3 times with $150 \mu \mathrm{l}$ of DEPC-treated pre-warmed $0.4 \mathrm{M} \mathrm{NaOH}$ with $0.25 \%$ Tween 20 . The strips were incubated at $50^{\circ} \mathrm{C}$ for $15 \mathrm{~min}$ followed by 3 more washes. The strips were then washed 3 times in DEPC-treated reverse osmosis (RO) water $(<2 \mu \mathrm{S})$, soaked for $5 \mathrm{~min}$, and then washed 3 more times with water. The wells were emptied thoroughly by tapping sharply several times upside down on a paper towel. Once dry, the strips were stored for up to 2 mo at $4^{\circ} \mathrm{C}$ in a clip-seal plastic bag.

Reverse transcriptase technique. NucleoLink wells were hydrated and blocked with $200 \mu$ of DIAPOPS buffer with $10 \mathrm{mg} \mathrm{ml}^{-1}$ fraction V BSA (prepared in DEPC-treated RO water $[<2 \mu \mathrm{S}]$ and filter-sterilised through a $0.2 \mu \mathrm{m}$ filter) at room temperature for $1 \mathrm{~h}$. The RT-PCR reaction mix contained $200 \mu \mathrm{M}$ each of dNTPs, $1.375 \mathrm{mM} \mathrm{MgSO}_{4}$ for Aeromonas salmonicida and $2 \mathrm{mM} \mathrm{MgSO}_{4}$ in all other cases, $1 \times$ RT-PCR buffer (Invitrogen), $0.1 \%$ DEPC-treated Tween 20, $3 \mu \mathrm{M}$ of each primer for Tenacibaculum maritimum, $2 \mu \mathrm{M}$ each primer for Lactococcus garvieae, and $2 \mu \mathrm{M}$ forward primer and $0.25 \mu \mathrm{M}$ reverse primer for A. salmonicida and Yersinia ruckeri, $0.2 \mu \mathrm{l}$ Superscript ${ }^{\mathrm{TM}}$ 1-step RTPCR with platinum Taq (Invitrogen), $3 \mu \mathrm{l}$ DNasetreated RNA, and sufficient $18 \mathrm{Mohm}$ water to bring the total reaction volume to $20 \mu \mathrm{l}$. Optimum conditions for PCR cycling were: cDNA from RNA at $50^{\circ} \mathrm{C}$ for 30 min followed by a 3 min denaturation at $94^{\circ} \mathrm{C}$, followed by 35 cycles consisting of denaturation at $94^{\circ} \mathrm{C}(45 \mathrm{~s})$, annealing at $62^{\circ} \mathrm{C}(45 \mathrm{~s})$ for $T$. maritimum and L. garvieae; annealing at $60^{\circ} \mathrm{C}(45 \mathrm{~s})$ for A. salmonicida and $Y$. ruckeri, extension at $72^{\circ} \mathrm{C}(45 \mathrm{~s})$, with a final extension at $72^{\circ} \mathrm{C}$ for $5 \mathrm{~min}$. A positive control, a nosample and a no-RT enzyme-negative control were included in each RT-PCR run.

DIAPOPS amplification was assessed by gel electrophoresis of amplicon generated in the liquid phase of the biphase PCR reaction.

Denaturation of non-covalently bound amplicons. Non-covalently bound solid-phase amplicons were removed by washing 3 times, soaking for $5 \mathrm{~min}$, and washing 3 more times with $0.2 \mathrm{M} \mathrm{NaOH}$ with $0.1 \%$ Tween 20 added just before use. 
The wells were then washed 3 times, soaked for 5 min and washed 3 more times in DIAPOPS buffer (80 mM Tris- $\mathrm{HCl}, 20 \mathrm{mM}$ Tris base, $150 \mathrm{mM} \mathrm{NaCl}$, $0.1 \%$ Tween 20, pH 7.5).

Hybridisation with biotin-labelled probes. A final concentration of $50 \mathrm{nM}$ denatured internal probe and $100 \mu \mathrm{g} \mathrm{ml}^{-1}$ salmon sperm DNA (Invitrogen) diluted in hybridisation solution $(6 \times$ standard saline citrate [SSC], $5 \times$ Denhardt's solution [Amresco], $0.1 \%$ Tween 20) were added to each well. Hybridisation was carried out at $50^{\circ} \mathrm{C}$ for at least $1 \mathrm{~h}$. Unbound probe was removed by washing 3 times in wash buffer $(0.5 \times \mathrm{SSC}$ with $0.1 \%$ Tween 20 ), soaking for $15 \mathrm{~min}$ at $50^{\circ} \mathrm{C}$ and washing 3 more times. After washing, the wells were emptied thoroughly by tapping sharply several times upside down onto a paper towel.

Colorimetric detection of labelled probes. Streptavidin alkaline phosphotase (Promega) was diluted 1:2000 in DIAPOPS buffer and $100 \mu \mathrm{l}$ was added to each well. The strips were incubated at $37^{\circ} \mathrm{C}$ for 1 to $2 \mathrm{~h}$. After incubation the wells were washed 3 times, soaked for $5 \mathrm{~min}$ and washed 3 more times with DIAPOPS buffer. Then, $100 \mu \mathrm{l}$ of $10 \mathrm{mg} \mathrm{ml}^{-1} p$-nitrophenylphosphate (Sigma-Aldrich) diluted in $1 \mathrm{M}$ diethanolamine with $1 \mathrm{mM} \mathrm{MgCl}_{2}$ (pH 9.8) was added to each well. Color development was allowed to proceed for $60 \mathrm{~min}$ in the dark at room temperature and OD readings at $405 \mathrm{~nm}$ were taken in an ELISA plate reader. If borderline positive/negative OD readings were obtained (values about 1.2 times the negative control after $60 \mathrm{~min}$ ), the reaction was allowed to proceed up to $18 \mathrm{~h}$. After this time, samples with absorbance readings of at least 1.4 times the highest negative control reading corresponded to samples that contained target RNA. If necessary, the EHA reaction was stopped with $100 \mu \mathrm{l}$ of $1 \mathrm{M} \mathrm{NaOH}$.

\section{RESULTS AND DISCUSSION}

\section{Sensitivity of RT-PCR-EHA}

As demonstrated for Yersinia ruckeri in Fig. 1, a sensitivity of $4 \mathrm{fg}$ or less was achieved for RT-PCREHA for each of the 4 bacteria from pure rRNA. This value was only possible when a conjugate ratio of 1:2000 was used; a lower conjugate ratio increased the background reading so that it was sometimes indistinguishable from weak positive reactions while, with a higher conjugate ratio, sensitivity was decreased. Primer concentration was critical in achieving optimum results. Primer concentration was optimised to give maximum sensitivity, so that agarose gel electrophoresis and EHA readings complemented each other. Reactions that

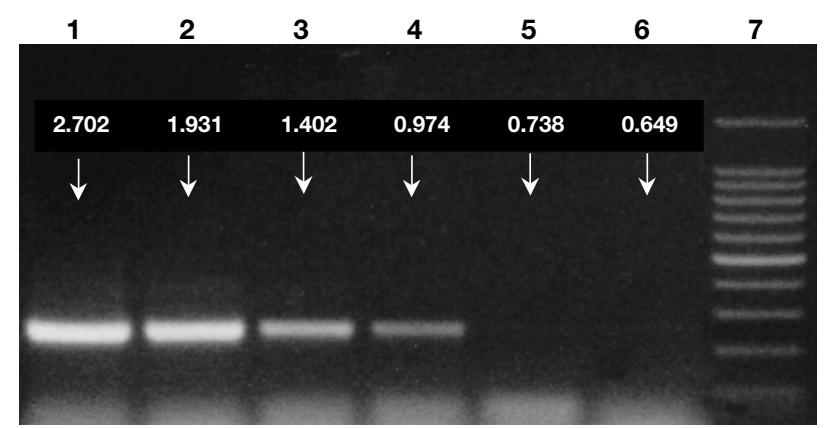

Fig. 1. Purified Yersina ruckeri RNA showing sensitivity of biphase PCR. Assessment by agarose gel electrophoresis and corresponding EHA readings. Lane 1: 4 pg RNA; Lane 2: 400 fg RNA; Lane 3: 40 fg RNA; Lane 4: 4 fg RNA; Lane 5: 0.4 fg RNA; Lane 6: negative control; Lane 7: Advanced Biotechnologies 100 bp ladder

gave a strong band and weak EHA readings or reactions that gave strong EHA and weak gel readings were considered sub-optimal. Optimum results were achieved for Aeromonas salmonicida and Y. ruckeri using a primer ratio of 1:8 as recommended for regular PCR-ELISA in NucleoLink tubes (Oroskar et al. 1996), however 4 times the recommended concentration of primer was required, that is $2 \mu \mathrm{M}$ of the forward and $0.25 \mu \mathrm{M}$ of the reverse primers (Fig. 2). This primer ratio resulted in inefficient RT-PCR-EHA when used with the other 2 bacteria. For Tenacibaculum maritimum and Lactococcus garvieae, a 1:1 ratio of the 2 primers at a concentration of $3 \mu \mathrm{M}$ each for $T$. maritimum and $2 \mu \mathrm{M}$ each for $L$. garvieae gave the best results.

The ability to distinguish weak positive results from negative background readings was tested by running 7 negative RT-PCR-EHA reactions alongside a weak positive (4 $\mathrm{fg}$ of template RNA) and repeating the experiment 2 times. In each case the weak positive gave a greater OD reading than the negative controls,

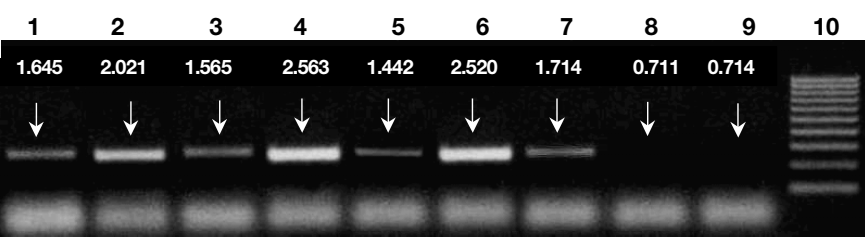

Fig. 2. Aeromonas salmonicida pure RNA. Effect of differing primer concentrations on agarose gel electrophoresis and EHA readings. Lanes 1 to 7: $1 \mathrm{pg}$ RNA: Lane 1: $2 \mu \mathrm{M}$ each primer; Lane 2: $2 \mu \mathrm{M}$ forward primer, $1 \mu \mathrm{M}$ reverse primer; Lane 3: $1 \mu \mathrm{M}$ each primer; Lane 4: $1 \mu \mathrm{M}$ forward primer, $0.5 \mu \mathrm{M}$ reverse primer; Lane 5: $0.5 \mu \mathrm{M}$ each primer; Lane 6: $2 \mu \mathrm{M}$ forward primer, $0.25 \mu \mathrm{M}$ reverse primer; Lane 7: $2 \mu \mathrm{M}$ forward primer, $0.5 \mu \mathrm{M}$ reverse primer; Lane 8: negative control with no RT enzyme; Lane 9: negative control with no RNA; Lane 10: Advanced Biotechnologies 100 bp ladder 


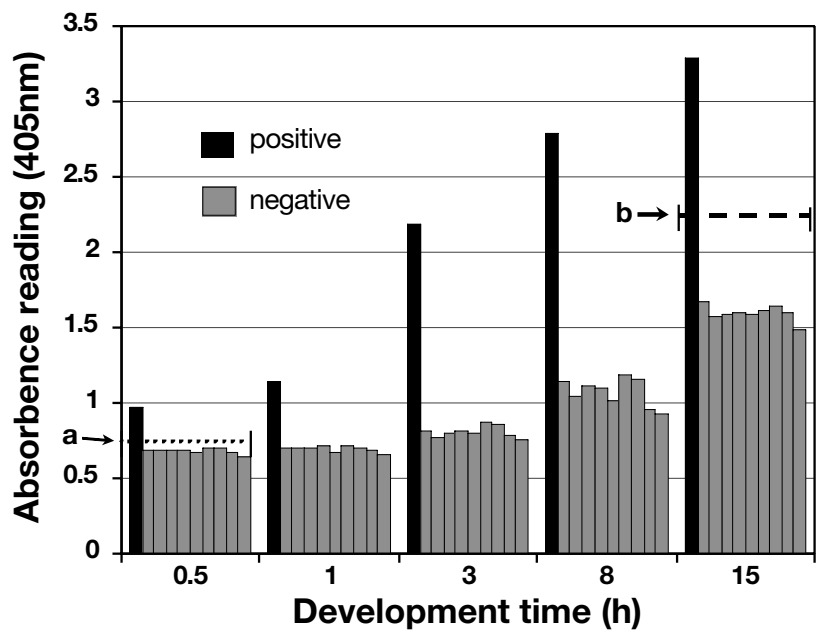

Fig. 3. Yersinia ruckeri. RT-PCR-EHA absorbance values showing difference between weak positive absorbance readings ( $4 \mathrm{fg}$ of template RNA) and 7 negative absorbance readings over time. Line a: cut-off value 1.2 times the highest negative control $(1.2 \times$ neg $=0.830)$ after $0.5 \mathrm{~h}$ incubation; Line $\mathrm{b}$ : cut-off value 1.4 times the highest negative control $(1.4 \times$ neg $=2.339$ ) after $15 \mathrm{~h}$ incubation

with the positive reading usually 1.2 times greater than the highest negative value after $0.5 \mathrm{~h}$, as shown for Yersinia ruckeri in Fig. 3. Occasionally, weak positive results were not easily differentiated from the negative controls even after $1 \mathrm{~h}$ developing time. In such cases, extending the color development period to $15 \mathrm{~h}$ was sufficient to separate the weak positive reactions from the negative values by a factor of at least 1.4.

Once optimised for pure RNA, the RT-PCR-EHA was tested on RNA extracted from selective-enrichment media using the vacuum system described. A sensitivity of $1 \mathrm{CFU}$ per $200 \mu \mathrm{l}$ sample volume was achieved for Aeromonas salmonicida and Tenacibaculum maritimum (Fig. 4), $9 \mathrm{CFU}$ for Lactococcus garvieae, and $3 \mathrm{CFU}$ for Yersinia ruckeri. The sensitivity achieved for L. garvieae was less than that achieved for the other bacteria. This was probably due to inefficient lysis during the RNA extraction procedure. Increasing the concentration of lysozyme or lengthening the incubation time did not improve sensitivity.

The sensitivity achieved using RNA extracted from the selective-enrichment media as RT-PCR template was slightly less than that achieved for the pure RNA, this was most likely due to limitations of the RNA extraction procedure. The main limitation to sensitivity in the procedure is the ability to add only one-quarter of the eluted RNA to a single RT-PCR reaction. During extraction, the bacterial RNA in a $200 \mu \mathrm{l}$ sample of enrichment-culture medium is concentrated to about $35 \mu \mathrm{l}$ of RNA elute, but to add this quantity to a single reaction, the total volume of the PCR mix would need

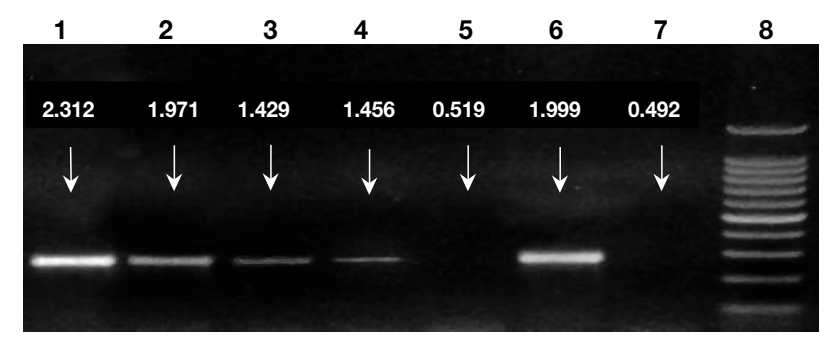

Fig. 4. Tenacibaculum maritimum RNA extracted from enrichment culture medium showing sensitivity of biphase PCR. Assessment by agarose gel electrophoresis and corresponding EHA readings. Lane 1: $1000 \mathrm{CFU}$ per $200 \mu \mathrm{l}$ sample volume; Lane 2: $100 \mathrm{CFU}$ per $200 \mu \mathrm{l}$ sample volume; Lane 3: $10 \mathrm{CFU}$ per $200 \mu \mathrm{l}$ sample volume; Lane 4: $1 \mathrm{CFU}$ per $200 \mu \mathrm{l}$ sample volume; Lane 5: $0.1 \mathrm{CFU}$ per $200 \mu \mathrm{l}$ sample volume; Lane 6: 10 pg positive control; Lane 7: negative control; Lane 8: Advanced Biotechnologies 100 bp ladder

to be significantly increased. While this is possible, the cost per test would be substantially increased. Were the total volume of eluted RNA to be used in 1 RT-PCR reaction, the sensitivity of the RT-PCR-EHA system for $200 \mu \mathrm{l}$ of enrichment broth would be an estimated $1 \mathrm{CFU}$ for each bacterium.

\section{Specificity of the RT-PCR-EHA}

The specificity of the PCR primers and corresponding internal probes were established previously (Carson 1998). For Tenacibaculum maritimum, Lactococcus garvieae and Yersinia ruckeri there is no reported evidence of cross-reaction with near-related species, as defined by phenotype or genotype. Similarly specificity is observed for Aeromonas salmonicida, with the exception that cross-reaction can occur with some strains of A. hydrophila and A. bestiarum (Carson 1998) which cannot be resolved by use of an internal A. salmonicida species probe (Høie et al. 1997). Due to this cross-reaction, positive A. salmonicida reactions are always confirmed by sequencing of the PCR amplicons or by performing biochemical tests (Carson et al. 2001) on the cultured organism. This high level of specificity of both primers and internal probes was observed using the NucleoLink RT-PCREHA system. This is demonstrated in Fig. 5, which shows the specificity results for T. maritimum. Clear, unambiguous reactions were evident, even with low concentrations of template RNA, and there was complete agreement between the presence of amplicon in the liquid-phase as detected by gel electrophoresis and the solid-phase amplicon as detected by EHA.

In conclusion, this study has described the development of RT-PCR-EHA in NucleoLink ${ }^{\mathrm{TM}}$ tubes. The system is optimised at every step to provide streamlined 


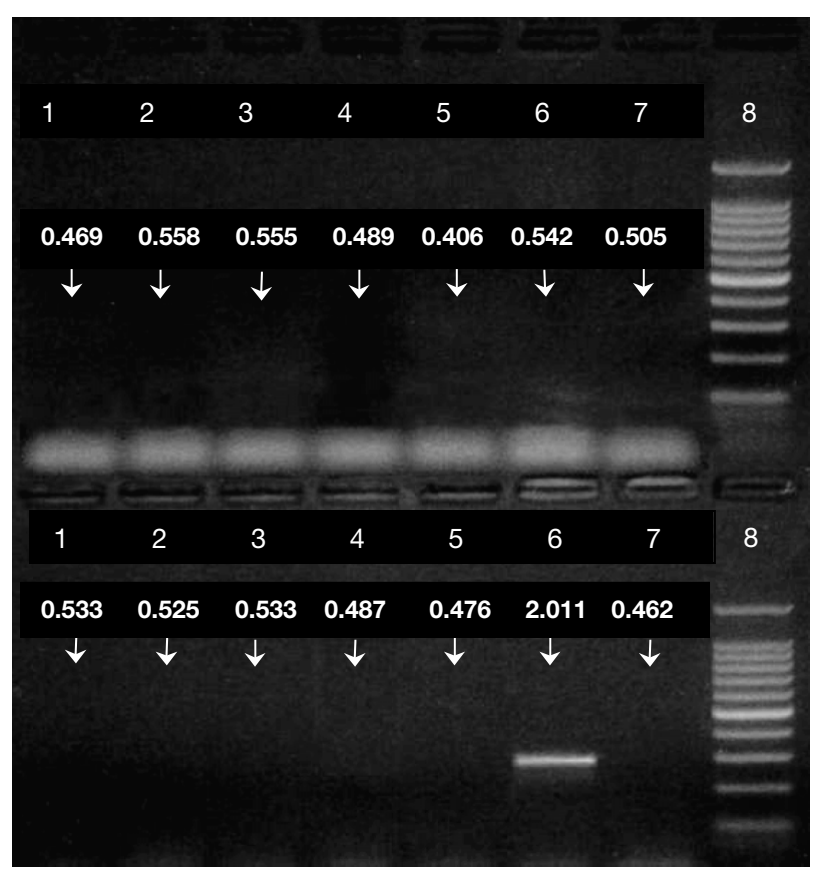

Fig. 5. Liquid-phase PCR results and corresponding EHA absorbance readings showing the specificity of the RT-PCREHA for Tenacibaculum maritimum. Top row, Lane 1: FCLB mucoid 89/2756-1; Lane 2: FCLB mucoid CRC-2; Lane 3: FCLB mucoid 89/2244-8; Lane 4: FCLB mucoid 89/3001-2; Lane 5: T. ovolyticum NCIMB $13127^{\mathrm{T}}$; Lane 6: Flavobacterium columnare NCIMB $2248^{\mathrm{T}}$; Lane 7 : Vibrio anguillarum 85/3475-1; Lane 8: Advanced Biotechnologies 100bp ladder. Bottom row, Lane 1: V. ordalii ATCC $33509^{\mathrm{T}}$; Lane 2: V. splendidus I ATCC 25914 ${ }^{\mathrm{T}}$; Lane 3: Cytophaga marinoflava ACAM 75; Lane 4: F. johnsoniae ATCC $17061^{\mathrm{Co}-\mathrm{T}}$; Lane 5: atypical Aeromonas salmonicida 93/956-2; Lane 6: T. maritimum NCIMB 2154 ${ }^{\mathrm{T}}$; Lane 7: negative control; Lane 8: Advanced Biotechnologies 100 bp ladder

high-throughput sampling. The use of 1 tube per sample from cDNA to EHA decreases the cost and time involved in sample transfer and decreases the risk of cross-contamination between samples. The system is also rapid with the 96-well RNA extraction to EHA results achieved in as little as $8 \mathrm{~h}$. An sensitivity of 4 fg for pure rRNA or 1 to $9 \mathrm{CFU}$ for selective-enrichment culture was achieved for the 4 bacterial fish pathogens Aeromonas salmonicida, Tenacibaculum maritimum, Lactococcus garvieae and Yersinia ruckeri. Work is in progress to validate this technology outside the laboratory to produce a powerful high-throughput system for surveillance and monitoring of pathogens in fish populations.

Acknowledgements. This research was funded by the Fisheries Research and Development Corporation, and the Tasmanian Department of Primary Industries, Water and Environment. We thank Nick Gudkovs, Australian Animal Health Laboratory, CSIRO, and Jane Oakey, University of Technology, Sydney, for supplying DNA for specificity-testing.

\section{LITERATURE CITED}

Barlic-Maganja D, Grom J (2001) Highly sensitive one-tube RT-PCR and microplate hybridisation assay for the detection and for the discrimination of classical swine fever virus from other pestiviruses. J Virol Methods 95:101-110

Bullock GL, Stuckey HM (1975) Aeromonas salmonicida: detection of asymptomatically infected trout. Prog FishCult 37:237-239

Carson J (1998) Development of molecular probes for use in bacterial disease diagnosis and health monitoring of farmed and wild finfish in Australia. Final Report on Project 93/128. Fisheries Research Development Corporation, Canberra

Carson J, Wagner T, Wilson T, Donachie L (2001) Miniaturized tests for computer-assisted identification of motile Aeromonas species with an improved probability matrix. J Appl Microbiol 90:90-200

Fitter S, Heuzenroeder M, Thomas CJ (1992) A combined PCR and selective enrichment method for rapid detection of Listeria monocytogenes. J Appl Bacteriol 73:53-59

Grennan B, O'Sullivan NA, Fallon R, Carroll C, Smith T, Glennon M, Maher M (2001) PCR-ELISAs for the detection of Campylobacter jejuni and Campylobacter coli in poultry samples. Biotechniques 30:602-605

Høie S, Heum M, Thoresen OF (1997) Evaluation of a polymerase chain reaction-based assay for the detection of Aeromonas salmonicida ssp. salmonicida in Atlantic salmon Salmo salar. Dis Aquat Org 30:27-35

Koo K, Jaykus LA (2000) Selective amplification of bacterial RNA: use of a DNA primer containing mismatched bases near its 3 ' terminus to reduce false-positive signals. Lett Appl Microbiol 31:187-192

Limbach FX, Jaulhac B, Piémont Y, Kuntz JL, Monteil H, Sibilia J (1999) One-step reverse transcriptase PCR method for detection of Borrelia burgdorferi mRNA in mouse lyme arthritis tissue samples. J Clin Microbiol 37: 2037-2039

Liolios L, Jenney A, Spelman D, Kotsimbos T, Catton M, Wesselingh S (2001) Comparison of a multiplex reverse transcription-PCR-enzyme hybridisation assay with conventional viral culture and immunofluorescence techniques for the detection of seven viral respiratory pathogen. J Clin Microbiol 39:2779-2783

Miles AA, Misra SS, Irwin JO (1938) The estimation of the bactericidal power of blood. J Hyg 38:732-749

Oroskar AA, Rasmussen SE, Rasmussen HN, Rasmussen SR, Sullivan BM, Johansson A (1996) Detection of immobilized amplicons by ELISA-like techniques. Clin Chem 42: $1547-1555$

Rasmussen SR, Rasmussen HB, Larsen MR, Jorgensen RH, Cano RJ (1994) Combined polymerase chain reaction hybridisation microplate assay used to detect bovine leukemia virus and Salmonella. Clin Chem 40:200-205

Rey L, Lambert V, Wattré P, Andréoletti L (2001) Detection of enteroviruses ribonucleic acid sequences in endomyocardial tissue from adult patients with chronic dilated cardiomyopathy by a rapid RT-PCR and hybridisation assay. J Med Virol 64:133-140

Song YL, Fryer JL, Rohovec JS (1988) Comparison of six media for the cultiviation of Flexibacter columnaris. Fish Pathol 23:91-94

Swaminathan B, Feng P (1994) Rapid detection of food-borne pathogenic bacteria. Annu Rev Microbiol 48:401-426

Thisted Lambertz S, Ballagi-Pordany A, Nilsson A, Norberg, Danielsson-Tham ML (1996) A comparison between a PCR method and a conventional culture method for 
detecting pathogenic Yersinia enterocolitica in food. J Appl Bacteriol 81:303-308

Whittington RJ, Djordjevic SP, Carson J, Callinan RB (1995)

Restriction endonuclease analysis of atypical Aeromonas salmonicida isolates from goldfish Carassius auratus, silver perch Bidyanus bidyanus and greenback flounder Rhombosolea tapirina in Australia. Dis Aquat Org 22: 185-191

Wilson T, Carson J (2001) Rapid, high-throughput extraction

Editorial responsibility: David Bruno,

Aberdeen, Scotland, UK of bacterial genomic DNA from selective-enrichment culture media. Lett Appl Microbiol 32:326-330

Wilson T, Carson J, Bowman J (2002) Optimisation of onetube PCR-ELISA to detect femtogram amounts of genomic DNA. J Microbiol Methods 51:163-170

Witham PK, Yamashiro CT, Livak KJ, Batt CA (1996) A PCRbased assay for the detection of Escherichia coli shiga-like toxin genes in ground beef. Appl Environ Microbiol 62: $1347-1353$

Submitted: May 22, 2002; Accepted: August 19, 2002

Proofs received from author(s): March 20, 2003 